\title{
MANAGERIAL INSPIRATION IN THE TRADITIONAL PESANTREN
}

Abdul Karim ${ }^{1}$ Mifedwil Jandra ${ }^{2}$

${ }^{1}$ The Faculty of Teachers Training and Education Program, University of Muhammadiyah Cirebon, West Java, Indonesia

${ }^{2}$ Centers of Research and Community Engagement (LPPM), Sunan Kalijaga State Islamic University, Yogyakarta, Indonesia

*Corresponding author: karim_gmail81@yahoo.co.id and jandraj6@gmail.com

\section{Article history}

Received:14/09/2015
Received in revised form:14/09/2015
Accepted: 18/10/2015

\begin{abstract}
This research deepens the concept of Henry Mintzberg who gives hard criticism that most managers can not be classified definitively into management functions. Thus allowing manager to play his/her managerial's roles which consist of interpersonal, informational, and decisional. So, this study will synthesize interpersonal's role of the managers. Meanwhile, an independent position of this research is the manager's inspiration to play his/her roles in decision making. The main objective of this research is leader's inspiration through the process of meditation, mediation, and reflection of the main Kyais in Pesantren Bendakerep Cirebon Indonesia. This objective can be answered deeply only with qualitative's kind of research through cultural approach. The data which is collected through interview, observation and documents analysis, after going through triangulation stage, will be analyzed through categorization, reduction, and interpretation. The findings show that the Kyai's efforts of decision making is by obeying the ancestor inheritances both materialistic and imaterialistic, to dig the inspiration through meditation, mediation and reflection in the form of decisions.
\end{abstract}

Keywords: Managerial roles, leadership inspiration, traditional pesantren 


\subsection{INTRODUCTION}

Scientifically, a manager builds and plans their policies (Carl A. Rodrigues, 2001), and naturally, many managers build their policies based on information (Daniel J. McCarthy, 2000), not to mention inwardly a manager preferred to trust in their hearts and inspiration (Daniel M. Cable, 2003). A new trend in the world of scientific management today is the management of spiritual, ethical and moral (David A. Jordan, 2005). Even researches, sources and methodology of managerial work (personal character) are still very little due to the difficultly working with them, but not a bit of research has uncovered the role of intuition in the working-world (Birgitte Ryslinge, 2009). In fact, a lot of data showed inspiration has become a major factor for effectiveness, efficiency and sustainability policies and institutions (Gisela Bohm, 2008).

In classical concept, management is a process of activities consist of planning, organizing, actuating, controlling, coordinating, directing, and leading (E. Mulyasa, 2009), and budgeting which is done to all resources (D. Sugiono, 2008) efficiently and effectively (C. Sergiovanni, 2003) through a person known as executor to achieve a short, middle, and long term goal. From these management theories, the author concludes the term management into three key words activities and its implementation, management function, and the goal which will be achieved.

In the context of different argumentation of management, the term "planning" means to arrange the decision and fuse between goals and resources (US Sa'ud, 2007). The term "organizing" means detail of planning execution and organization's structure application $(\mathrm{Ng}$. Purwanto, 1999) efficiently merge together (E. Dale, 1965). The meaning of "actuating" is the efforts in actuating various group's members (GR Terry, 1960), and realizing the planning to become real action (E. Mulyasa, 2003). The meaning of "controlling" is guiding, recording, explaining, cultivating, uncurling, observing (E. Mulyasa, 2003), investigating, monitoring, supervising, curbing, evaluating, and correcting (M. Manullang, 1992; GR. Terry, 1977). The controlling points to all things that miss the target and error (E. Mulyasa, 2009) or divergence (GR. Terry, 1977) done by subordinate (M. Manullang, 1992), wrong direction of manager and all determine principles. In essentials, controling means to correct the planning (GR. Terry, 1960), organizing, and actuating.

According to the contradiction above, the discussion regarding a manager's action towards his/her management did function but not optimal (Solihin, 2010; Parmin, 2009; Oktarina, 2011; Veranika, 2005; Ningrum, 2008). With the result, there is an idiom, "where the programme to be planned more, so it will not increasingly actuated". In addition, the fact that a manager often practices his/her managerial roles, gives priority to his/her personal character and indigenous values (J. Durcan etal, 1995; G. Beekmand, 1984; E. Setiawan, 2010; F. Mas'ud, 2004). Sometimes the roles strongly affect the leader's local culture (M. Cole, 1995; HC.Triandis in AA Kresna, 2011; Matsumoto, 2004; G. Beekman, 1984). Not only that, management function theory causes organization structure's to become wide but the function minimize along with highcost/capital budgeting needs (Newstex GB, 2011; R. Singh, 2011; G. Dondero, 1996; L. Powell, 2002), so it will be difficult to apply in new institution, non-profit, and institution under bankruptcy. In addition, one management functions expertly and others differently. This indicates that management theory is not free of values, un-universal, also is not the only one (AA. Kresna, 2011; B. Ryslinge, 2009). So it is difficult to apply the theory in the institution that is based on values, beliefs and norms. Mintzberg (Mintzberg, 1975; JT. Murphy, 2006; RJ.Lewicki, 2005; MH. Lubatkin, 1997; DM. Cable, 2003) gives hard criticism that most managers do not definitively classified into management functions.

This research proves that most of the time, all managers rely their decision making on the inspiration. Inspiration is the main aspect of effectiveness and efficiencies of Islamic education institution especially pesantren. This inspiration will be elaborate systematicly into meditation, mediation and reflection of manager's decision. 


\subsection{FORMULATION OF STUDY AND METHODOLOGY}

According to the facts and debates/gap above, the author has not found any discussion on the aspect of personal character mainly the inspiration. Thus, the author intends to examine the distinctive style of Kyai in the traditional pesantren that puts beliefs, values, and norms in their management. The core question is how Kyai's put the effort to internalize the inspiration into determining the policies of the pesantren? Through three indicators, namely; how Kyai's put the efforts to get the inspiration? How Kyai mediates the inspiration into his personal? And, how Kyai's put the efforts to reflect the policies into his managerial role?

The main goal of this study is to prove that the management of educational institutions will be better, if the manager could be able to internalize their inspiration in decision-making. The main goal will also be enhanced with the response of the problem formulation above. Thus, this study is done in order to find the data of Kyai's effort to get inspiration, a variety of ways to mediate it in his personal, and data about the reflection techniques of policy in his managerial roles.

The formulation of this study started with how the Kyai's put the effort to internalize the inspiration into decision making? This formula can be answered deeply only with qualitative's kind of research through cultural approach. Descriptive method is used to determine the process of inspiration, namely: meditation and mediation (managerial inspiration). The ex post facto method is used to determine the intuition Kyai and his reflection. Both methods are done by using in-depth interviews, and observation. The data which is collected from these instruments after going through triangulation stage will be analyzed by categorization, reduction, and interpretation (Pupu S. Rahmat, 2009; Suharsimi Arikunto, 2006).

\subsection{THE DISCOURSE OF MANAGERIAL'S ROLE}

In order to complete the writing and clarify the study, the author passes several studies that have been done previously by other authors on managerial's role and personal character. With the result later, the presentation or implementation of this paper can be more focused and systematic.

The importance of managerial's role is endorsed with "The nature of managerial work in developing countries: a limited test of the Universalist hypothesis." The results showed some facts which refute the universal hypothesis (Michael H. Lubatkin, 1997). This study recommends the following study to discuss about beliefs and norms. Also other research titled "Are the classical management functions useful in describing the managerial work?" is about the basis of manager's work using qualitative methods to integrate the concept of Fayol as the classical function theory with the concept of managerial roles of Mintzberg. Classical function provides clarity and the different methods of how to classify the thousands of different activities of the manager's job and the various techniques which used in function terms to achieve organizational goals (Stephen J. Carrol, 1987).

The different study between author such as Lubatkin and Carroll is the study about spiritual aspect and inspiration as manager's personal which used as a managerial's source of Mintzberg. Whereas, Lubatkin emphasis on methodological convergence between Mintzberg and Fayol, and Carroll emphasis on both experts theory.

In that managerial role, the study of "The nature of managerial work" explained the theory of management functions is not invulnerable of critic (Henry Mintzberg, 1973). This study gives hard critique that most of the manager's job cannot be classified definitely into five functions. Managerial role is an organized arrangement of behavior, which is identified by its position. His new views regarding the management does not invite much criticism and he is generally regarded as a good description of manager's job. The concept of managerial roles provides a good framework for the better design of manners. It believes that the position of manager gives formal power which is performed by an organizational unit, so managers can play his/her roles. It is included in three categories: interpersonal, informational, and desisional. With regard to un- 
universality of management theory, the "Mitos keuniversalan teori manajemen Amerika" concludes that there is no universal in the management theory, either from America or other countries (Michael H. Lubatkin, 1997; F. Mas’ud, 2004; Jerome T. Murphy, 2006).

\subsection{THE CHARACTERISTIC OF INSPIRATION}

The characteristic of native psychology is intuitive and transcendent in the spirituality side, and contemplative in the subjectivity side, it is through reflective method, particularist and specifical which is used in trying to understand spirituality. About culture, it is defined as culture when it has more close by informal aspects of organization than formal elements which are denoted as structure. The culture focuses on values, beliefs and norms of individual and how these perceptions join with the meanings of the organization (AA. Kresna, 2012, T. Bush etal, 2012, B. Ryslinge, 2009; K. Kerfoot, 2003; G. Böhm, 2008). Actually, with this intuition, it is enough to lead a college community or other organization. This aspect produces the intuition and instincts that will help us in learning how to creat a great leaders and also affect on decision-making and liaison.

Based on the study of managerial's role and intuition above, the author assumes that the manager can play a managerial's role not only in the interpersonal but also intuition aspects necessarily associated with interpersonal's manager especially the aspect of spiritual in the form of inspiration. Therefore, the independent position of this study emphasizes on the inspiration of leaders in carrying out the management of religious institutions. The efforts and inspiration attitude of the leadership is associated with interpersonal roles of Mintzberg and with the intuition initiated by Ryslinge. But according to the author, formally, interpersonal role is more physical and purely empirical and still at the level of management theory. Meanwhile the author applies managerial's role in the field of education based on the inspiration (Henry Mintzberg, 1973; B. Ryslinge, 2009). The reason is that national culture still believes in the transcendental and spiritual side. Although the leadership inspiration is intuitive but it is more obvious through the process of meditation, mediation and reflection in applying management theory which adapted them with the needs and local culture, as well as connecting with the power of god (the presence of the spiritual side) (F. Mas'ud, 2004; Wolfson in Duerr, 2004).

The author draws the process of managerial inspiration as design bellow:

The Process of Managerial Inspiration

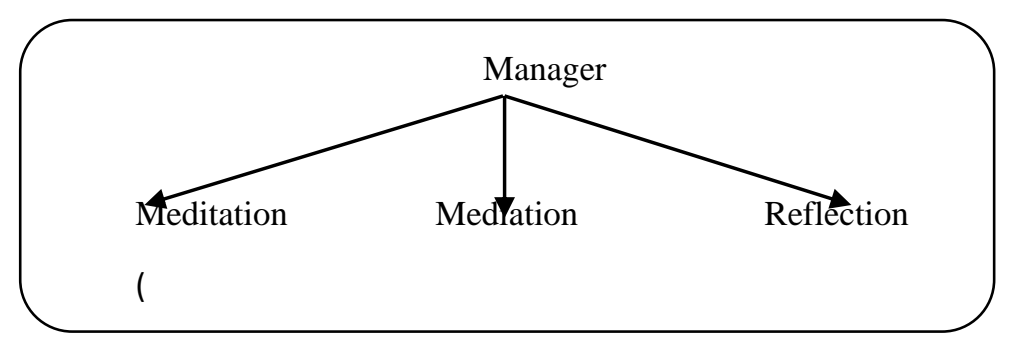

\subsection{THE ANCESTOR OF PESANTREN BENDAKEREP}

Lineage of ancestor in Benda is Sunan Gunung Jati--Mbah Soleh (great-grandfather)--KH. Abu Bakar-KH. Ahmad Fakih--KH. M. Miftah--KH. Ismail--KH. Kholil. The ancestor has two types of genealogical's offspring which are through blood and mursyid (teacher-student's correlation). It is said that ancestor's Kyai in Benda is a fighter during the Dutch colonial period. This ancestral struggle should be told from generation to generation as a history and as an appreciation for their services. At that time, the ancestor was fasting (Riyadlah) for 9 years; 3 years for him self, 3 years for his families and 3 years for his santri so that this pesantren is standing until now (Interviews with KH. M. Miftah, 2015). 
Lineage Inspiration

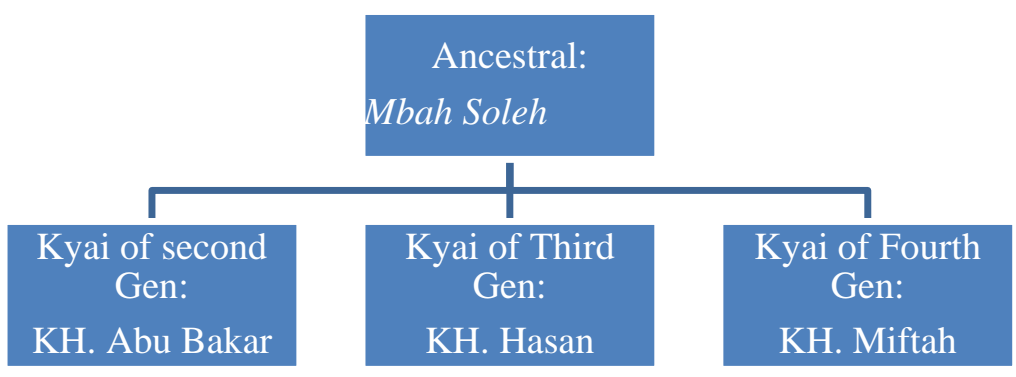

The older Kyai in Benda is KH. Hasan. He is the youngest (last child) of Kyai Fakih family. The following elders Kyai are still alive: KH. Hasan, KH. Miftah, KH. Ismail Azmatkhan, KH. Abdulloh (are called by Fourt Generation Kyai). Km, H. Hasan stays in the left/south of the mosque. Meanwhile, last of Azmatkhan name which embedded by elder Kyai in Benda Kerep as a gift pedigree name of Pakistan. In Benda, it is usually belief the senior as elderly through several indicators: the nature of brother (older brother/descentof blood) and the ability/knowledge, because Benda is a Muslim community ordered to glorify the elder and science. The age of Kyai Ismail now is sixty years. In the brother view, Kyai Kholil is the youngest (last child). But in the sister view, he is the fifth (before last child) of six siblings (Interviews with KH. Isma'il, 2015). The fourth generation Kyai does not consider ancestral relics as sacred objects, including objects that attached to his body like Akik stone. It is considered that the object has its advantages but without any benefit, so it is only considered as accessories not gusti (sacred), except those immaterials (Interviews with KH. Kholil, 2015).

In Benda, to be Kyai is an automatic process and without inauguration. It could be said that there is indeed an element of descendent in Kyai, because as a child of Kyai, from beginning of the birth he has to be Kyai because all Kyai is to be like a great-grandfather of Mbah Soleh. But, not all the children of Kyai in Benda could be a Kyai. Therefore, through their education or ngaji they will become a Kyai, along with the blessings of the ancestors, and the wish of God. Thus, the ancestral lineage is not enough to guarantee the position, because ancestor stresses to their lineage to ngaji (to read Al-Qur'an). But certainly, in Benda all Kyai are men and they do not feel like they are a Kyai, hence it cannot be mentioned when is the exact time they began to be a Kyai and take the position. Additionally, Kyai's daughter should be married by students who is the off spring of Mbah Soleh (Interviews with KH. Kholil, 2015).

The insights and ancestor inheritages are the decree to obey the Islamic law both orders and prohibitions of Allah, sincerity, kindness, steps of ancestral in the form of learning method even Bandungan nor sorogan, the order to learn (ngaji) Al-Qur' an in order to become virtuous people, and surrogate of mosque's spirituality. This heritage is based on ancestor's fear on young generation's life in the future age. Such behavior is closer to the meaning of commitment (Noor Miyono, 2013)

There two type of Ancestral relics which are the material and immaterial. The material's heritage is the Akik stone, stick, turban, Imamat, and mudeng (roof of mosque). The immaterials heritage is in the form of teaching of the Al-Qur'an and Sunnah, sainthood and thought, Tarekat Syathariyah, and all good fatwas. The remains of ancestors, especially Mbah Soleh, spread a lot not only in Benda but also in Buntet and Mundu (Interviews with KH. Kholil, 2015).

\subsection{THE MEDITATION, MEDIATION AND REFLECTION OF KYAI}

A Kyai beliefs that life in the world is for the hereafter, so the ways to contemplate among the fourth generation Kyai are to read wirid that is inherited from their mursyid after five time prayers, to read the Al-Qur'an, shalawat, to perform sunah fasting in Senin-Kamis (MondayThursday) with a pure heart and sincerity. Spiritual leaders often do yoga and meditation as daily activities (Duerr, 2004). These activities are carried out on special time, and oftenly done in the 
yard of the ancestral home. There is tarikat Syathariyahin Benda as a relic of Mbah Soleh (Interviews with KH. Hasan, KH. Isma'il, KH. M. Miftah, KH. Kholil, 2015).

There are some Kyai's efforts to find the inspiration and have certain attitudes towards their dream and thought. Besides the obedience towards the ancestral insight, the effort of Kyai to get inspiration is through reading and learning of the classic book (kitab kuning). Inspiration can also be obtained through natural's tafakkur, wisdom awareness, being near (takarub) to God, to follow the ethics, the environment and themselves, to know how to manage the heart, as well as understand the purpose of life and evaluate themselves. The behavior contemplative one with reflections and do what they believed (Beer, 2010). Where there is the result of a dream it will be tailored to the ability of the santris. The dream's result of fourth generation Kyai is ordinary different with ancestor done. So they argue that fruit of thought is blessing of wasilah from their ancestor, read a prayer, istighfar and shalawat to become policies. Intuition is the main capital to lead an organization (Ryslinge, 2009). In Benda, there is no "planning" but living habit such as haul. The planning is interpreted without a pronounced just desired in the heart, because of fraid to be fail or Gludug ketiga (thunderclap in dry season). The Kyai give the alms sincerely and halal without Blantik or in order god will be granted their desire (Interviews with KH. M. Miftah \& KH. Kholil, 2015).

In addition to the internal efforts, a Kyai also get the inspiration from their almamater. A Kyai beliefs there is a blessing (tabarruk) of their teacher in pesantren where they were learning before even in Semarang, Demak, or Pati regarding leadership styles and methods such as: the system Sorogan, Bandungan, and rules of pesantren. But for many matters, the fourth generations Kyai learn everything from his parents, KH. Fakih (Interviews with KH. M. Miftah, 2015).

The fourth generation Kyai tries to do the same as the ancestor which is done little by little, from generation to generation and from mouth to mouth known as ngaji and its kitab kuning (even there is no lost), and takes care of the children and santri. Among the way to conserve ancestor inheritance is through endeavor and prayer, also joint together with family and society. Concerning to personality, it is imposible to act the same as the ancestor, due to the fourth generation Kyai differences in Tarekat degrees. So, they will continuously do everything like now without holding out the past, there is no reason except that Benda is a worship's Barometer of Cirebon by proclaiming worship and increasing piety to Allah (Interviews with KH. Isma'il, 2015).

A Kyai only obey the ancestor's steps to continue ngaji as a hereafter provisions. In the ngaji there is no contradiction, but if in the school, it happen because its goal is the world upheaval. Ancestral knows that the future age will be getting chaotic so he ordered his descendants to continue ngaji. To live in Benda is a gift of God. Citizens of Benda do not feel they are best, they then do not need to use coat and tie because there is no office but they also merely lived in the village or forest (Interviews with KH. M. Miftah, 2015).

In Benda, a Kyai is neutral, they do not differentiate the people, so the pesantren is still running even without technology and structural organization. Kyai lionize the practice, fatwa ancestors, and Islamic perception according to the Sunnah waljamaah ideology. As a form of relationship (silaturahmi), the communication among Kyai is built sometimes once a week, in the thalil event, and the day of Eid to discuss the student's activities and hostel.

The decisions reflects a Kyai inpirational's procces who is more concerned with the goodness and capabilities of the santri. For example: A Kyai provides all the books, and then the students determine their own choices. So, the ngaji activity depends on the talent of the santri for their provision in the community. These three activities (meditation, meditation, and reflection) are assumed to be a factor for the speed pesantren (Heru Subandono, 2011).

The decisions of a Kyai as above is observed by the santri and subordinates. Kyai's subordinates are workers as sympathizer and some of senior santri as helpers, but all are in unity. The honest order is one aspects of decisions obeyed. Leaders who are concerned with the 
subordinate policy are often termed transcendent leadership (Chavis, 2011). A Kyai learns to figure and does not only obey when they were learning in the past. But the principle, the adherence arised from the students themselves, because they still consider the Kyai as a teacher and parents, an exalted people, also as a source of barakah (blessings) and karamah (miracles) (Interviews with KH. Isma'il, 2015).

The teaching, fatwa, and relics of ancestral is the source of inspiration to the third and the fourth generation of Kyai. Then, a Kyai tries to continue this inheritance by holding strongly to these inspiration in decision making of the santri, pondok (boarding), alumnus, mosque, electric, family and culture. The authors draw bellow:

Inspiration-based Decision

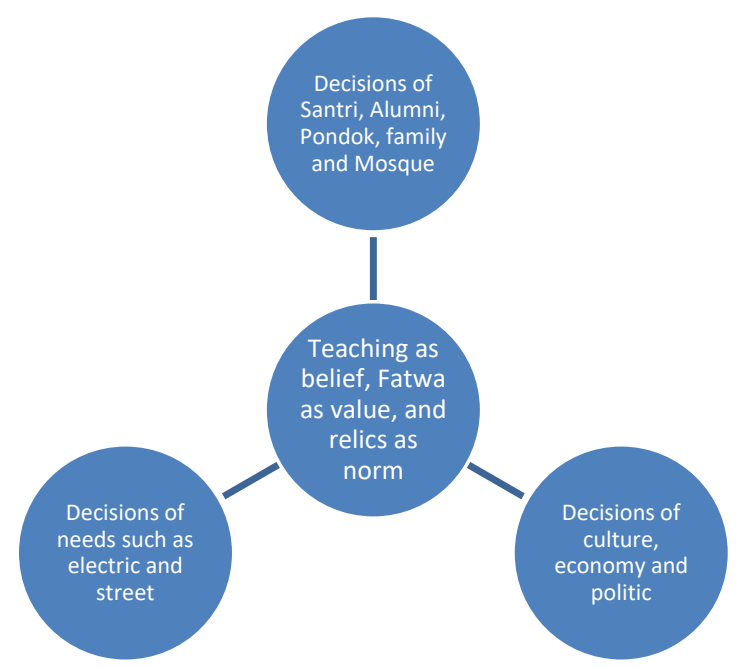

\subsection{SUMMARY OF INSPIRATION-BASED DECISION OF SANTRI, NEEDS AND CULTURE OF KYAI}

Although the number of Kyai \& Nyai is in big quantities, it does not mean the santri is great too. The important aspect is berkah. The santri has 40-50/hostels tailored to the availability of Kyai and facilities. Acording to KH. Kholil, it is destiny and extra ordinary for pesantren with its santri in big quantities. There is no annual administration of santri because it is not important. A Kyai has the principle that doing good thing is unnecessary to mention again. The girl's santri in Benda use cawet yashmak. According to a Kyai that yashmak in the city is a fashion (appearance) so some boys become likes her, in case in Benda, they are comfortable with the long material yashmak, because it is intended to cover the genitalia (interviews with KH. M. Miftah \& KH. Kholil, 2015).

The hostel in Benda has 4 buildings without the ravine, each held by fourth generation Kyai. In the hostel of Kyai Miftah, santri are charged IDR 35.000 for early enter and IDR 10.000/a month for electricity, while the kitchen needs are taken care by the santri themselves, sleeping on mats and carpet. The finance for the building is coming from the Kyai and the support from any success alumnus without asking the government. But, a Kyai did not refuse the support from the government; the important is without any proposals and reports, only the proposal to God. If there is a need of funds for building they will inform from mouth to mouth of among the santri and alumnus. In the hostel of Kyai Kholil there is a grant from the Swiss bank through the government but without proposal. In Benda, the proposal interpreted as beg to God when there is a concept, a strong desire (for 10 years) and the purposes of building granting. So, when receiving the helps mean as grace of god and granted prayer. While, some workers of hostel building process are professional and some other are voluntary (interviews with KH. M. Miftah, 2015).

There is no decision from a Kyai to change the ngaji to be a school because of it's straining of administration and birocracy. There is the elementary schools (SD) in the society but the goal 
is only for reading, writing and summing. The similarity with the school is the subject of Jurisprudence (Fikih), Theology (Ushuludin) and a certificate (in the case of KH. Miftah's hostel). However, a Kyai gives certificate only for those who wants to go to the next level. Candidate of a santri who would get into a school are advised to join the school in Buntet, Kempek and Babakan (those places of other pesantren in Cirebon which hold the school). The Kyai allows the learning of the general theory as long as they returned to the Al-Qur'an so morality is present. Knowledge is good as long as it carried out not for material interest. Money and work cannot achieved by it's offspring except based on concern, prayers, efforts, and trust. Simply, the science of religion is more extensive than at school, because the Al-Qur'an is a source of knowledge, santri in Benda can be pitted about al- ' $\mathrm{lm}$ with the students, teachers and lectures even the professor (Interviews with KH. M. Miftah, 2015).

In Benda there is a bond of alumnus. The identity of alumnus are as an implementer and act like a pioneer. Positive behavior is the basis for the progress of the pesantren plus the good quality of the alumni (Nurkolis, 2013). Also there is a famous alumnus who became a speaker. By implementing the knowledge, they will increase and obtained the unknown science. Many people are smart but not necessarily have a good personality. A Kyai is grateful to stay in the pesantren because Allah has saved them. Perhaps, a Kyai may be more voracious than others if he is outside. Case: there are many corruption in the world outside although they are manny smart people. So in Benda, Kyai are not a corruptor, because there is no opportunity and money to be corrupted (Interviews with KH. Isma'il \& KH. Kholil, 2015).

The Mosque becomes a vortex of Mbah Soleh's family, for them to get close to the mosque, so the ties among their offspring are stronger. Thus, the Kyai who stay far from the mosque are distant descendants. They are family and cousin of same generation. Last time (Mbah Soleh's era), the population is still in small number and the land was available, so Mbah Soleh sons are placed in a circle of the mosque so that they would take care of it, even so sweeping the yard around. The formulation of offspring in Benda is "ya besan ya misan". Besan is relationship between parents whose children are married and misan is cousin. The mosque in Benda is a comfortable place to worship because of the blessing by generation to generation and their role in taking care of the mosque. Logically, the location of the mosque is away from the hustle/bustle of urban causing appeasement of worship. The mosque is a central place of blessing, because it produces a multitude of goodness (Interviews with KH. Isma'il \& KH. Kholil, 2015).

In the past there was no electricity, not for reasons of mystique, but the electricity did not reach the region of Bendakerep. Due to the urgent need, in the 1988-89 electricity has been entered, but there is an agreement that the community should used without $\mathrm{TV}$, radio and sound in the mosque, worried it will disturb the students/children, keeping off bad things, so if it exist, it will be confiscated. Despite of that, the electricity is used to spread the religion and the only purpose of electricity is for lighting. If it is calculated from rural electrification in 1980, the needed time to discuss about entry of electricity with students and the community is about 8 years, it is due to concerns about the negative impact of electricity and electric is considered to quickly damage the eyes of santri and less bright. Case: The first, lantern can be used for 6 people in one room, now 10 watt of lamp is not enough. Besides electricity, the change in Benda is an access of road (street) from the rocks/ground to the asphalt because now almost every Kyai have vehicles. Also the changes place for eat from using teak to the plate because the teak is now very rare (Interviews with KH. Isma'il, 2015).

Not all descendants of Mbah Soleh stay in the pesantren, because there are two cases who has built the pesantren outside, namely: Kyai Ahmad at Megu Cilik Weru and in Tugu. This shows the greatness and wisdom of God. Likewise with the alumnus, indeed once there were 100 graduates in the class which went all out and spread throughout Indonesia, there is in Aceh, Brunei and Jakarta. For Kyai in Benda, they have a large mandate that went on procession of ancestral heritage and culture of Islam. With the previews analogical: if all the alumnus living in Benda, how to contain them, while they are needed by people to spread the religion. The hostel in 
Benda likened in a smallshop, there is a buyer and available so will be served (interviews with KH. Hasan, 2015).

A Kyai does not discriminate the community in Bendakerep and it makes them submissive and obedient to the Kyai. Behavioral response is a characteristic variants giver of true policy (Bruno-Jofre, 2011). Not surprisingly, there is a positive relationship between Kyai and the society. There is a Kyai who used to mediate the conflicts between Forkwal (Communication Forum of Wali Town) communities with the local TV that allegedly contain elements of missionaris, by simply helping NU only for non-physical, non-structural and non-material (just prayers and thoughts). Kyai does has relation with outside activities as they have representatives inside the pesantren. Else, Kyai has built networking with alumnus, family, and government (Head \& Mayor) who came to lodge without any interest and the relationship is neutral. A Kyai does approach, and giving knowledge in organizations (branch, region, NU) but it does not make organization. They have kinship with KH. Sa'id in Pesantren Gedongan and KH. Abbas in Buntet, but Mbah Soleh is the older person (Interviews with KH. M. Miftah, 2015).

Kyai responds positively to the culture as long as it does not get out of Islamic law. The politics must be based on Islamic strategy to become orderly, peaceful both macro and micro, and is not guided from India or China because the culture will be in disorder. Whereas about economy, the society does it by themselves. A Kyai just remind those who have been able to do it, by giving alms (tasarufan) as any part of their job for example is haul program.To Kyai, it is shown by some businesses like selling fabrics, accessories hordeng, and tapestries that goes internationally, especially in Asia. These businesses are done only to sustain the running of pesantren. So, it is natural to see many cars in the garage before entering the territory of Benda and used to smooth dakwah to the people. Lastly regarding politics, a Kyai is very familiar to it, but they does not take part in politics because they argue that it is full with falsehood and intrics. In Benda they continue to hold polling in the elections as a form of good citizens. The Kyai is disappointed with an early marriage such as the case of Sheih Puji which is considered as a sexual harassment, while the officials "snack" considered it as usual thing. Meanwhile, organizations and Islamic forums, the board and council of scholars remained quiet regarding the issue (Interviews with KH. M. Miftah, 2015).

\subsection{CONCLUSION}

From the above findings, the author concludes some points as follows: Kyai's efforts in decision making are to obey the ancestor's inheritage both material and immaterial, to draw inspiration through meditation, mediation and then do the reflection in the form of decisions. Description of meditation, mediation and reflection, namely: (1) A Kyai's efforts to get inspiration is from what they read and study, natural tafakkur, approaching to God, ethic to others and environment and themselves, and understand the purpose of life and correct themselves; (2) A Kyai tries to resemble ancestors from generation to generation by mouth to mouth, pray to be consistent with it, to cooperate with family in order to remind each other, along with the students in order to preserve ngaji and with the community in order to support each other. A Kyai tries to be neutral in the community and to simplify the problem but do not underestimate all affairs; (3) A Kyai tries to be a figure not just to give an example, but also to attend the kindness and ability of subordinates, promote the unity and brotherhood, prioritize the blessing (ziyadatul khaer), prioritize after life eternally, uphold the principle of practice, keep spirituality, also give priority to hearafter needs rather than earthly desires, and try to consisten with adap-asor (down-up equility) principal. 


\section{References}

Agus, Arawati \& Hajinoor, Mohd Shukri. (2012). Lean Production Supply Chain Management as Driver Towards Enhancing Product Quality and Business Performance; Case Study of Manufacturing Companies in Malaysia. Universiti Kebangsaan Malaysia. InternationalJournal of Quality and Reliability Management. Emerald Group Publishing Limited. Vol. 29 No. 1. pp 92121.

Arikunto, Suharsimi. (2006). Prosedur Penelitian Suatu Pendekatan Praktek. Jakarta: Rineka Cipta.

Böhm, Gisela and Brun, Wibecke. (2008). "Intuition and affect in risk perception and decision making, Faculty of Psychology University of Bergen," Judgment and decision making, Vol. 3, No. 1. Pp 1-4.

Bush, Tony \& Marianne Coleman. (2012). Manajemen Mutu Kepemimpinan Pendidikan. Yogyakarta: IRCiSoD Diva Press.

Bruno-Jofré, Rosa;Hills, George (Skip). (2011). Changing Visions Of Excellence In Ontario School Policy: The Case. Educational Theory; ProQuest Vol. 61, No. 3. pp 335.

Chavis, Benjamin F, Jr. (2011). President Barack Obama's Transcendent Leadership. San Bernardino United States Calif: Precinct Reporter ProQuest Public Health. Volume. 47. Edisi 2. pp A4.

ChinaRealNews. (2012). Great wall motor to realize flat management. Chatham: Newstex. Retrieved from http://search.proquest.com/docview/1017631032? accountid=25704. pp 1-3.

Church, Maria Jaime. (2005) Intuition, Leadership, and Decision Making: A Phenomenon. (A Dissertation). University Of Phoenix. UMI. 3177390. pp 100-103.

Duerr, Maia. (2004). "The contemplative organization.” Journal of Organizational Change Management. Vol. 17. No. 1. ProQuest. pp 43-58.

Fakhruddin, Agus. (2011). Prinsip-Prinsip manajemen pendidikan Islam dalam Konteks Persekolahan. Jurnal Pendidikan Agama Islam-Ta'lim, Vol. 9, No. 2. pp 199-211.

Fayol, Henri. (1949). General and Industrial Management. New York, NY: Pitman.

Furchan, Arif. (2002). Metode Penelitian Kualitatif. Yogyakarta: Rake Sarasin.

Hersey P, Blanchard KH. (2004). Management of Organizational Behavior: Utilizing Human Resources, 4thEd. Jakarta: Erlangga.

Jeffry S. Babb, Jr., Herbert E. Longenecker, Jr., Charles R. Woratschek, Amjad Abdullat. (2012). Engaging in Reflective Decision-Making: The Role of Skills in the Development of the Information Systems Undergraduate Curriculum. West Texas A\&M University, University of South Alabama, Robert Morris University, West Texas A\&M University. Journal of Higher Education Theory and Practice. Vol. 12. No. 2. pp 20-29.

Jordan, David A. (2005). A Phenomenological Study of Transcendent Leaders in Healthcare," UMI Number: 3161350. pp 274.

Karim, Abdul DS. (2011). Peran Kyai dan Kopontren dalam Pembentukan Mental Kemandirian \& Kewirausahaan Santri. (Tesis). Cirebon: IAIN Syeh Nurjati.

, Abdul DS. (2012). Manajemen Rasa \& Syahwat. Cirebon: Hirahpress.

Kerfoot, Karlene. (2003). Learning intuition - less college and more kindergarten': The leader's challenge. Nursing Economics; 21, 5; ProQuest. pp 253.

Komanee, Sukhamit., Hoxsuwan, Suttipong., \& Phusee-on, Songsak. (2013). The Contemplative Education Learning Environment Management Model for Undergraduate Students. Mahasarakam University, Thailand. The Journal of Global Business Management. Volume 9. Number 3. pp 1624. 
Kresna, Aryaning Arya. (2011). Perspektif Filososfis Psikologi Pribumi: Sebuah Paradigm Baru Bagi Psikologi Jawa.” Jurnal Psikologi. Universitas Multimedia Nusantara Tangerang. pp 63-71.

Manullang, M. (2008). Manajemen Personalia.Yogyakarta: Gajah Mada University Press.

Mas'ud, Fuad. (2004). "Mitos Keuniversalan Teori Manajemen Amerika.” Jurnal Studi Manajemen \& Organisasi. Vol. 1 No. 1. pp 10-20.

Matsumoto, David. (2004). Pengantar Psikologi Lintas Budaya. (Terjemahan). Yogyakarta: Pustaka Pelajar.

Michel, John W. Devin L. Wallace, \& Rachel A. Rawlings. (2013). Charismatic leaders: the Role of Admiration and System Justification. Leadership \& Organization Development Journal. Vol. 34 No. 5. pp 469-487.

Milheim, Karen Lorraine. (2008). Learning Through Reflective Practice: Professional Development Of Adult Basic Education Program Managers. A Dissertation in Adult Education. UMI. 3346349. ProQuest. pp 148-150.

Mintzberg, Henry. (1975). The Manager's Job: Folklore and Fact. Harvard Business Review, Vol. 53. pp 49-61.

, Henry. (1973). the Nature of Managerial Work. New York: Harper \& Row. pp 132-152.

, Henry and Jerome T. Murphy. (2006). "An Interview with Henry Mintzberg," The Phi

Delta Kappan, Vol. 87, No. 7. pp 527-528.

Miyono, Noor. (2013). Komitmen Menjadi Kepala Sekolah Berkualitas Melalui Otoritas Profesional dan Moral. PPs IKIP PGRI Semarang. JMP, Volume 2, Nomor 1. pp 56-66.

Montambault, Patricia. (2005). Politiques Gouvernementales Canadiennes et Prise En Charge En Milieu Autochtone. UMI, Département D'anthropologie Faculté Des Sciences Socials Université Laval Québec. pp 1-17.

Muhaimin, Suti'ah dan Sugeng Listyo Prabowo. (2010). Manajemen Pendidikan Aplikasinya dalam Penyusunan Rencana Pengembangan Sekolah/Madrasah. Jakarta: Kencana.

Mulyasa, E. (2009). Manajemen Berbasis Sekolah. Bandung: PT. Remaja Rosdakarya.

Murni, Sri. (2010). Pengaruh Kepemimpinan Kepala Sekolah dan Motivasi Kerja Guru terhadap Kinerja Guru SD Negeri Di Kecamatan Dukuhwaru Kabupaten Tegal.Semarang: UNNES Press. pp 255-285.

Nurhadi, Mulyani A., \& Nur Kholis, \& A. Mukti Bisri. (2008). Manajemen Madrasah Satu Atap. Bandung: Penerbit Nuansa.

Nurkolis. (2012). Pentingkah Peran Manajemen Bagi Peningkatan Kualitas Sekolah?JMP, PPs Universitas Negeri Jakarta, Volume 1 Nomor 3. pp 257.

, (April 2013). Potret Birokrasi Pendidikan Di Indonesia. PPs IKIP PGRI Semarang. JMP, Vol. 2, No. 1. pp 44-55.

Oktarina, Tenny. (2011). Optimalisasi Fungsi Manajemen Pengetahuan Dalam Manjemen Proyek Melalui Intervensi Pengembangan Manajer Lini Pada PT. XYZ. (Tesis). Program Studi Ilmu Psikologi. Depok: UI.

Parmin. (2009). Hubungan Pelaksanaan Fungsi Manajemen Kepala Ruangan Dengan Motivasi Perawat Pelaksana Di Ruang Rawat Inap RSUP Undata Palu. (Tesis). Magister Ilmu Keperawatan. Jakarta: Uinversitas Indonesia.

Paternoster, Ray \& Pogarsky, Greg. (2009). Rational Choice, Agency and Thoughtfully Reflective Decision Making: The Short and Long-Term Consequences of Making Good Choices. DOI 10.1007/s10940-009-9065-y. J Quant Criminol. pp 103-127. 
Peters, Wayne. (2012). Indigenous Knowledge Can Enrich Our Campuses" CAUT Bulletin; ProQuest Education Journals. Vol. 59, No. 1. pp A3

Powell, Loraine. (2002). Shedding a tier: Flattening organisational structures and employee empowerment," The International Journal of Educational Management, Vol. 16, No. 1; ProQuest. pp 54-59.

Qodratilah, Meity Taqdir. (2011). Kamus Bahasa Indonesia untuk Pelajar.Jakarta Timur: Badan pengembangan dan pembinaan Bahasa.

Rahmat, Pupu Saeful. (2009). Penelitian Kualitatif. Equilibrium, vol. 5, no. 9. pp 1-8.

Rodrigues, Carl A. (2001). Fayol's 14 Principles of Management then and now: a Framework for managing today's organizations effectively. Montclair State University, New Jersey, USA. Management Decision. 39/10. pp 880-889.

Ryslinge, Birgitte. (2009). Mindful Intuition: An Effective Leadership Response to the Community College Environment."Marshall Goldsmith School of Management, Organizational Psychology Division San Francisco Alliant International University, UMI Number: 3377428. pp 220-223.

Sa'ud, Udin Syaefudin et.al. (2007). Perencanaan Pendidikan, Suatu Pendekatan Komprehensif. Bandung: PT. Remaja Rosda Karya.

Sadler-Smith, Eugene and Erella Shefy. (2007). Developing Intuitive Awareness in Management Education. Academy of Management Learning \& Education, Vol. 6, No. 2. pp 186-205.

Safaria, Triantoro. (2004). Kepemimpinan. Yogyakarta: Graha Ilmu.

Sari, Dewi Puspita. (2013). Kontribusi Gaya Kepemimpinan Kepala Sekolah Dan Motivasi Berprestasi Guru Terhadap Mutu Pendidikan Di Gugus Rama 2 UPT DISDIKPORA Kecamatan Kembang Kabupaten Jepara. PPs Manajemen Pendidikan IKIP PGRI Semarang. JMP, Volume 2. Nomor 1. pp 102-103.

Setiawan, Ebta. (2010). Kamus Besar Bahasa Indonesi Offline Versi 1.1.

Shein, Esther. (2012). A Flatter, Simpler Network. Computerworld, Vol. 46, No. 13; ProQuest. pp 30.

Sidi, Ahmad. (2009). Upaya Yayasan dan Pimpinan Universitas Dalam Peningkatan Sumberdaya Manusia di Perguruan Tinggi: Studi Multi Situs di Universitas Obor 1, Universitas Obor 2, Universitas Obor 3. pp 360-374.

Singh, Rajni. (2011). Job Enrichment: A prerequisite for change management" GMJ, Volume V, Issue $1 \& 2$, January-December. pp 39-44.

Skordoulis, Rosemary and Dawson, Patrick. (2007). Reflective decisions: the use of Socratic Dialogue in Managing Organizational Change." University of Aberdeen Business School, Aberdeen, UK.Management Decision.Vol.45 No. 6. @ Emerald Group Publishing Limited.00251747. DOI 10.1108/00251740710762044. pp 991-1007.

Solihin. (2010). Aplikasi Fungsi Manajemen Dakwah pada Program Siaran Agama Islam PT. Cipta TPI," Skripsi, Fakultas Ilmu Dakwah dan Komunikasi. Jakarta: UIN Syahid.

Sopiah. (2008) Perilaku Organisasi. Yogyakarta: Andi.

Stewart, Penni. (2010). Trent Leads in Recognition of Indigenous Knowledge. CAUT BulletinProQuest Education Journals. Volume 57, No. 6. pp A3.

Stewart, Rosemary. (2005). Studies Of Managerial Jobs: Methodologies And Profiles. International Studies of Management \& Organization, Vol. 2, No. 1, the Study of Roy J. Lewicki, "Jerry Jurgensen, Chief Executive Officer of Nationwide, on Mintzberg's Managers Not MBAs." Academy of Management Learning \& Education, Vol. 4, No. 2. pp 240-243. 
Subandono, Heru. (2011). Kepemimpinan Kepala Sekolah dalam Membentuk Motivasi Kerja Guru (Studi Kasus di Sekolah Masjid Terminal Depok Propinsi Jawa Barat) (Tesis) Program Studi Ilmu Administrasi. Fakultas Ilmu Social dan Ilmu Politik. Universitas Indonesia. pp 1-126.

Sukendar, Nur Cahya Edi. (2013). Pengaruh Keterampilan Kepemimpinan Kepala Sekolah Dan Motivasi Kerja Guru Terhadap Kinerja Guru Smp Negeri Di Sub Rayon 03 Kabupaten Jepara. PPs Manajemen Pendidikan IKIP PGRI Semarang.JMP, Volume 2 Nomor 1. pp 67-82.

Terry, George R. (2006). Prinsip-Prinsip Manajemen. Jakarta: Bumi Aksara.

Tilaar, HAR. (2009) Kekuasaan Dan Pendidikan; Manajemen Pendidikan Nasional Dalam Pusaran Kekuasaan. (Jakarta: PT Rineka Cipta.

Tim Dosen. (2011). Pedoman Penulisan. Bahasa Indonesia, Transliterasi, dan Pembuatan Notes Dalam Karya Ilmiah. Jakarta: SPs. UIN Syarif Hidayatullah.

Veranika. (2005). Audit manajemen fungsi keuangan. ’Skripsi. Fakultas Ekonomi-akuntansi. Semarang: Universitas Katolik Soegijapranata.

Wahyuni, Setia \& Syarkawi, Nandang Hidayat. (n.y). "Hubungan antara Komunikasi Interpersonal Kepala Sekolah dan Peran Manajerial Kepala Sekolah dengan Kepuasan Kerja Guru. pp 52-60.

Yukl, Gary A. (2005). Kepemimpinan Dalam Organisasi. (Terjemahan oleh Jusuf Udaya). Jakarta: Prehalindo. 